\title{
SAGITTAL CURVE AND HIGH METAL DENSITY IN ADOLESCENT IDIOPATHIC SCOLIOSIS
}

\author{
CURVA SAGITAL E ALTA DENSIDADE METÁLICA NA ESCOLIOSE IDIOPÁTICA \\ DO ADOLESCENTE
}

\section{CURVA SAGITAL Y ALTA DENSIDAD METÁLICA EN LA ESCOLIOSIS IDIOPÁTICA DEL ADOLESCENTE}

Fabio Araújo Fernandes ${ }^{1}$, João Paulo Machado Bergamaschi', Luciano Antonio Nassar Pellegrino', Ricardo Shigueaki Galhego Umeta', Maria Fernanda Silber Caffaro ${ }^{1}$, Robert Meves, Osmar Avanzi ${ }^{1}$

\begin{abstract}
Objectives: To analyze radiographically the postoperative kyphosis from patients undergoing surgical treatment for AIS with pedicle screws in all vertebrae included in the arthrodesis. Methods: Retrospective study. The following measurements were evaluated: Cobb angle in anteroposterior radiograph of the three curves (proximal thoracic, main thoracic, and lumbar), Cobb angle in the lateral view of the two curves: thoracic kyphosis (T5-T12) and lumbar lordosis (T12-S1). Results: Of the 25 patients evaluated preoperatively, four (16\%) were hypokyphotic, 20 patients (80\%) were normokyphotic and only one (4\%) was hyperkyphotic. For hypokyphotic and hiperkyphotic patients a satisfactory correction of thoracic kyphosis was obtained in $100 \%$ of cases, which was preserved in the final result. The same pattern of thoracic kyphosis was observed for all normokyphotic patients throughout the follow-up. Conclusion: Radiographic evaluation of thoracic kyphosis in patients with AIS treated surgically with pedicle screws in all vertebrae showed satisfactory results with respect to the correction of thoracic kyphosis.
\end{abstract}

Keywords: Spine; Kyphosis; Surgical procedures, operative; Bone screws.

\begin{abstract}
RESUMO
Objetivos: Analisar radiograficamente a cifose no pós-operatório dos pacientes submetidos ao tratamento cirúrgico da ElA com parafusos pediculares em todas as vértebras envolvidas na artrodese. Métodos: Estudo retrospectivo. Foram avaliadas as seguintes medidas: ângulo de Cobb na radiografia em incidência anteroposterior das três curvas (torácica proximal, torácica principal e lombar), ângulo de Cobb na radiografia em perfil das duas curvas: cifose torácica (T5-T12) e da lordose lombar (T12-S1). Resultados: Do total dos 25 pacientes avaliados no pré-operatório, quatro (16\%) eram hipocifóticos, 20 pacientes (80\%) eram normocifóticos e apenas um (4\%) era hipercifótico. No caso dos pacientes hipocifóticos e hipercifóticos, obtivemos correção satisfatória da cifose torácica em 100\% dos casos, os quais se apresentaram normocifóticos no resultado final. Os pacientes normocifóticos permaneceram com esse mesmo padrão de cifose torácica em sua totalidade durante o seguimento. Conclusão: A avaliação radiográfica da cifose torácica em portadores de escoliose idiopática do adolescente tratada cirurgicamente com parafusos pediculares em todas as vértebras envolvidas na artrodese demonstrou resultados satisfatórios com relação à correção da cifose torácica.
\end{abstract}

Descritores: Coluna vertebral; Cifose; Procedimentos cirúrgicos operatórios; Parafusos ósseos.

\section{RESUMEN}

Objetivos: Analizar radiográficamente la cifosis postoperatoria de pacientes sometidos a tratamiento quirúrgico por ElA con tornillos pediculares en todas las vértebras incluidas en la artrodesis. Métodos: Estudio retrospectivo. Se evaluaron las siguientes medidas: ángulo de Cobb en el plano antero-posterior de las tres curvas (torácica proximal, torácica principal y lumbar), ángulo de Cobb en el plano lateral de las dos curvas: cifosis torácica (T5-T12) y lordosis lumbar (T12-S1). Resultados: De los 25 pacientes evaluados en el preoperatorio, cuatro (16\%) eran hipocifóticos, 20 (80\%) eran normocifóticos y sólo uno (4\%) era hipercifótico. Para los pacientes hipocifóticos y hiperkyphotic fue obtenida corrección satisfactoria de la cifosis torácica en el 100\% de los casos, los cuales se presentaron normocifóticos en el resultado final. Se observó el mismo patrón de cifosis torácica para todos los pacientes normocifóticos durante todo el seguimiento. Conclusión: La evaluación radiográfica de la cifosis torácica en los pacientes con escoliosis idiopática del adolescente tratados quirúrgicamente con tornillos pediculares en todas las vértebras mostró resultados satisfactorios con respecto a la corrección de la cifosis torácica.

Descriptores: Columna vertebral; Cifosis; Procedimientos quirúrgicos operativos; Tornillos óseos.

\section{INTRODUCTION}

Adolescent idiopathic scoliosis (AIS) is a three-dimensional structural deformity of the spine that occurs in healthy individuals during puberty. AIS is the most common form of scoliosis and it is usually diagnosed by exclusion. Several studies show that $1 \%$ to $3 \%$ of children between 10 and 16 years of age have some degree of curvature of the spine, though in most cases surgical intervention is not necessary. ${ }^{1,2}$ There is a lot of controversy about the natural evolution of untreated AIS, the importance of surgical correction ${ }^{3,4}$, and the ideal implant to be used. ${ }^{5-7}$ The main objectives of surgical treat-

1. Faculdade de Ciências Médicas da Santa Casa de São Paulo (FCMSCSP), São Paulo, SP, Brazil.

Study conducted at the Spine Group of the Department of Orthopedics and Traumatology of Irmandade Santa Casa de Misericórdia de São Paulo (ISCMSP), São Paulo, SP, Brazil. Correspondence: Rua Peixoto Gomide, 493, apto 163. 01409-001 - Jardim Paulista, São Paulo, SP, Brasil. fabiof14@ hotmail.com 
ment of AIS are: (1) to prevent the progression of the curve through solid fusion, (2) to achieve a permanent correction of the deformity. (3) to improve appearance, (4) to improve psychosocial health, (5) to reduce the development of low back pain, degenerative changes, and functional disability, and (6) to reduce cardiopulmonary involvement during adulthood. Surgical treatment of AIS is indicated when the primary curve presents a Cobb angle in the coronal plane greater than $40^{\circ}$ in skeletally immature patients. ${ }^{3}$ A thorough knowledge of the natural history of untreated AIS is essential for a correct evaluation of the outcome of surgical treatment, and to determine whether the benefits outweigh the risks. ${ }^{8}$

A third-generation posterior instrumentation was developed by Cotrel-Dubousset, in 1984, using rods combined with hooks. ${ }^{9}$ Compared to the other techniques described, its benefits are mainly related to improved correction of the frontal, sagittal, and rotational planes. ${ }^{10}$ Several surgical techniques have been performed to correct deformity over the years and, more recently, correction using pedicle screws has become a reference for treatment. ${ }^{10-13}$

The optimal surgical treatment for AIS requires correcting the coronal deformity of the main thoracic curve, improving posture, and achieving balance of the sagittal and coronal axes with the shoulders aligned and parallel with the pelvis. ${ }^{14-16}$

The alignment of the spine in the sagittal plane is not yet well understood, and many methods have been used to measure this alignment, but to date there is no effective system to evaluate the spine in this plane. ${ }^{17}$

Long-term follow-up of patients with surgically-treated AIS has shown that some cases evolve with rectification of both the thoracic kyphosis (TK) and the lumbar lordosis (LL), known as flat back syndrome. This syndrome includes back pain, degenerative disc disease, and functional disability. ${ }^{14}$

Patients with primary thoracic scoliosis are typically hypokyphotic compared to patients without scoliosis. ${ }^{18}$ Recent studies have evaluated the influence of arthrodesis on TK and general sagittal alignment. Depending on the type of instrumentation and the technique used for correction, postoperative TK may increase or decrease ${ }^{10,13,18}$ and can interfere with the radiographic parameters of the profile.

Achieving a trunk that is balanced in both the coronal and sagittal planes is a major challenge in the treatment of AIS. This study is therefore important for increasing knowledge, and for an adequate understanding of the correction of this pathology, particularly in relation to the evaluation of kyphosis during the postoperative period.

\section{METHODS}

Following project approval by the Research Ethics Committee of the Institution (number 213/11), we selected case histories of patients diagnosed with AIS in the Department of Orthopedics and Traumatology between January 2005 and May 2011 who underwent posterior approach deformity correction surgery and arthrodesis, using third-generation instrumentation of all the vertebrae included in the arthrodesis. The radiographic images were evaluated both pre- and postoperatively, and during follow-up. Anterior-posterior (AP) and profile (P) views of the spine in the orthostatic position were evaluated for magnitude of the curve, using the Cobb method. ${ }^{19}$

Angle measurements of the proximal thoracic curve, the main thoracic curve, and the lumbar curve were taken in AP view, while the angle measurements of thoracic kyphosis (T5 to T12) and lumbar lordosis (T12 to S1) were obtained in profile view. The curves were classified according to the criteria of Lenke et $\mathrm{a}^{20}$ and King et al. ${ }^{21}$

As inclusion criteria, patients diagnosed with adolescent idiopathic scoliosis who had undergone surgical treatment with pedicle screws in all the vertebrae included in the arthrodesis with a minimum follow-up time of six months were considered. Patients with scoliosis associated with neuromuscular disease, patients submitted to other surgical procedures or those with another type of implant, and also those who had required anterior access surgery for correction of the deformity were excluded.

\section{RESULTS}

Of the 25 patients analyzed, $88 \%$ were female and $12 \%$ were male. Their ages varied between 11 and 18 years, with an average of 14 years of age. (Table 1 )

Applying the Lenke classification to the pattern of the curve in the coronal plane, there were 23 patients (92\%) of type I, 2 (8\%) of type $\mathrm{II}$, and none (0\%) of the other types. Regarding the lumbar modifier, 12 patients (48\%) were classified as type A, 13 (52\%) as type B, and none $(0 \%)$ as type $C$. In terms of the thoracic modifier, which considers sagittal alignment, 22 patients (88\%) were normokyphotic (between 10 and $\left.40^{\circ}\right)$, one case $(4 \%)$ was hyperkyphotic $\left(<40^{\circ}\right)$, and $2(8 \%)$ were hypokyphotic $\left(<10^{\circ}\right)$. (Table 2$)$

In terms of the King classification, four patients (16\%) were type 2,21 patients $(84 \%)$ were type 3 , and there were no patients $(0 \%)$ of the other types.

The preoperative coronal Cobb angle values varied between $12^{\circ}$ and $55^{\circ}$ in the proximal thoracic curve, with an average angle of $26.2^{\circ}$, between $45^{\circ}$ and $78^{\circ}$ in the main thoracic curve, with an average of $60.6^{\circ}$, and between $2^{\circ}$ and $55^{\circ}$ in the lumbar/thoracolumbar curve, with an average of $35.3^{\circ}$. The average curve flexibility was $35 \%$ for the proximal thoracic curves, $44 \%$ for the main thoracic curves, and $86 \%$ for the lumbar/thoracolumbar curves. (Table 3 )

The postoperative coronal Cobb angle values varied between $5^{\circ}$ and $28^{\circ}$ in the proximal thoracic curve, with an average angle of $14.1^{\circ}$, between $0^{\circ}$ and $45^{\circ}$ in the main thoracic curve, with an average

Table 1. Clinical characteristics.

\begin{tabular}{c|c}
\hline Number of patients & $\mathbf{2 5}$ \\
\hline Female/Male & $22 / 3$ \\
\hline Age (years) & $14.2(11-18)$ \\
\hline Duration of follow-up (months) & $18.2(6-32)$ \\
\hline The values are presented as absolute values or averages (minimum-maximum).
\end{tabular}

Table 2. Results of the study of sagittal curves.

\begin{tabular}{|c|c|c|c|c|c|c|c|c|c|}
\hline \multirow[b]{2}{*}{ Patient } & \multirow[b]{2}{*}{ Age } & \multirow[b]{2}{*}{ Sex } & \multirow[b]{2}{*}{ King } & \multirow[b]{2}{*}{ Lenke } & \multirow[b]{2}{*}{ Levels } & \multicolumn{2}{|c|}{$\begin{array}{c}\text { Preop } \\
\text { sagittal }\left({ }^{\circ}\right)\end{array}$} & \multicolumn{2}{|c|}{$\begin{array}{c}\text { Postop } \\
\text { sagittal }\left({ }^{\circ}\right)\end{array}$} \\
\hline & & & & & & \begin{tabular}{|l|} 
T5-T12 \\
\end{tabular} & T12-S1 & T5-T12 & T12-S1 \\
\hline 1 & 15 & $\mathrm{~F}$ & 3 & $2 \mathrm{BN}$ & T3-L1 & 28 & 60 & 20 & 50 \\
\hline 2 & 12 & $\mathrm{~F}$ & 3 & $1 \mathrm{BN}$ & T4-L1 & 20 & 30 & 14 & 12 \\
\hline 3 & 15 & $\mathrm{~F}$ & 3 & $2 \mathrm{BN}$ & T4-L1 & 25 & 30 & 20 & 25 \\
\hline 4 & 18 & $\mathrm{~F}$ & 3 & $1 \mathrm{BN}$ & T4-L1 & 20 & 42 & 22 & 25 \\
\hline 5 & 14 & $\mathrm{~F}$ & 3 & $1 \mathrm{AN}$ & T4-T12 & 10 & 36 & 12 & 20 \\
\hline 6 & 14 & $\mathrm{~F}$ & 2 & $1 \mathrm{~B}+$ & T4-T12 & 45 & 43 & 20 & 20 \\
\hline 7 & 14 & $\mathrm{~F}$ & 2 & $1 \mathrm{BN}$ & T5-L1 & 40 & 32 & 21 & 36 \\
\hline 8 & 16 & $\mathrm{~F}$ & 3 & $1 \mathrm{AN}$ & T5-T12 & 28 & 30 & 34 & 48 \\
\hline 9 & 12 & $\mathrm{~F}$ & 3 & $1 \mathrm{AN}$ & T4-L1 & 38 & 42 & 25 & 36 \\
\hline 10 & 13 & $\mathrm{~F}$ & 3 & $1 \mathrm{AN}$ & T5-L1 & 16 & 49 & 18 & 45 \\
\hline 11 & 12 & $\mathrm{~F}$ & 3 & $1 \mathrm{AN}$ & T4-L1 & 7 & 22 & 16 & 26 \\
\hline 12 & 13 & $\mathrm{~F}$ & 3 & $1 \mathrm{BN}$ & T4-L1 & 13 & 25 & 24 & 40 \\
\hline 13 & 15 & $\mathrm{M}$ & 3 & $1 \mathrm{BN}$ & T4-L1 & 40 & 58 & 28 & 48 \\
\hline 14 & 14 & $\mathrm{~F}$ & 3 & IAN & T4-L1 & 12 & 50 & 18 & 47 \\
\hline 15 & 11 & $\mathrm{~F}$ & 3 & 1B- & T4-L1 & 3 & 31 & 23 & 48 \\
\hline 16 & 17 & $\mathrm{~F}$ & 3 & $1 \mathrm{AN}$ & T4-L1 & 17 & 36 & 26 & 36 \\
\hline 17 & 13 & $\mathrm{~F}$ & 3 & $1 \mathrm{AN}$ & T5-L1 & 22 & 50 & 24 & 42 \\
\hline 18 & 17 & $\mathrm{~F}$ & 3 & $1 \mathrm{~A}-$ & T5-L1 & 7 & 46 & 20 & 30 \\
\hline 19 & 15 & $\mathrm{M}$ & 3 & $1 \mathrm{BN}$ & T5-L1 & 5 & 46 & 22 & 44 \\
\hline 20 & 15 & $\mathrm{~F}$ & 2 & $1 \mathrm{BN}$ & T6-T12 & 18 & 53 & 22 & 51 \\
\hline 21 & 12 & $\mathrm{~F}$ & 2 & $1 \mathrm{BN}$ & T4-T12 & 26 & 42 & 28 & 51 \\
\hline 22 & 16 & $\mathrm{M}$ & 3 & $1 \mathrm{AN}$ & T5-L1 & 32 & 43 & 26 & 44 \\
\hline 23 & 13 & $\mathrm{~F}$ & 3 & $1 \mathrm{AN}$ & T5-L1 & 21 & 50 & 20 & 45 \\
\hline 24 & 18 & $\mathrm{~F}$ & 3 & $1 \mathrm{AN}$ & T4-L1 & 30 & 47 & 34 & 36 \\
\hline 25 & 12 & $\mathrm{~F}$ & 3 & $1 \mathrm{BN}$ & T4-T11 & 38 & 45 & 37 & 39 \\
\hline
\end{tabular}


of $20.0^{\circ}$, and between $0^{\circ}$ and $28^{\circ}$ in the lumbar/thoracolumbar curve, with an average of $13.7^{\circ}$. The percentage of correction was $44.5 \%$ in the proximal thoracic curve, $66.4 \%$ in the main thoracic curve, and $59.6 \%$ in the lumbar/thoracolumbar curve. (Table 3 )

In the sagittal plane study (Tables 2 and 4), preoperative kyphosis varied between $5^{\circ}$ and $45^{\circ}$, with an average of $22.4^{\circ}$, and preoperative lordosis varied between $22^{\circ}$ and $60^{\circ}$, with an average of $41.5^{\circ}$. In the postoperative period, we found kyphosis varying between $12^{\circ}$ and $37^{\circ}$, with an average of $23.6^{\circ}$, and lordosis between $12^{\circ}$ and $51^{\circ}$, with an average of $37.7^{\circ}$.

There were no cases of infection or neurological complications.

In the total group of patients evaluated preoperatively, there were 4 cases (16\%) of hypokyphosis, 20 cases (80\%) of normokyphosis, and one case (4\%) of hyperkyphosis. In the case of the hypokyphotic and hyperkyphotic patients, we obtained satisfactory correction of the thoracic kyphosis in $100 \%$ of the cases, with the end result being normokyphosis. All the normokyphotic patients (100\%) maintained the same standard of thoracic kyphosis during follow-up. (Table 5)

Table 3. Results in the coronal plane (averages).

\begin{tabular}{c|c|c|c|c}
\hline & Preop $\left({ }^{\circ}\right)$ & Flexibility & Postop ( $\left.{ }^{\circ}\right)$ & Correction \\
\hline Proximal thoracic curve & $26.2(12-55)$ & $35 \%$ & $14.1(5-28)$ & $44.5 \%$ \\
\hline Main thoracic curve & $60.6(45-78)$ & $44 \%$ & $20.0(0-45)$ & $66.4 \%$ \\
\hline Lumbar curve & $35.3(2-55)$ & $86 \%$ & $13.7(0-28)$ & $59.6 \%$ \\
\hline
\end{tabular}

The values are presented as averages (minimum- maximum).

Table 4. Results in the sagittal plane.

\begin{tabular}{c|c|c|c}
\hline & Preop ( $\left.{ }^{\circ}\right)$ & Postop $\left(^{\circ}\right)$ & Correction \\
\hline Kyphosis & $22.4(5-45)$ & $23.6(12-37)$ & $2 \%$ \\
\hline Lordosis & $41.5(22-60)$ & $37.7(12-51)$ & $-10 \%$ \\
\hline
\end{tabular}

The values are presented as averages (minimum-maximum).

Table 5. Study of kyphosis.

\begin{tabular}{c|c|c}
\hline & Preop & Postop \\
\hline Hypokyphosis $\left(<10^{\circ}\right)$ & $16 \%(4)$ & $0 \%(0)$ \\
\hline Normokyphosis $\left(10-40^{\circ}\right)$ & $80 \%(20)$ & $100 \%(25)$ \\
\hline Hyperkyphosis $\left(>40^{\circ}\right)$ & $4 \%(1)$ & $0 \%(0)$ \\
\hline
\end{tabular}

The cases are presented as a percentage (absolute number).

\section{DISCUSSION}

AIS is a complex, three-dimensional deformity that affects the spine and the rib cage. Cases with curves of great magnitude and the potential for progression require surgical treatment. Currently, surgical techniques are almost always associated with instrumentation, which increases stability and has a higher potential for correction. ${ }^{22}$

Different scoliosis classification systems have been described, attempting to categorize models of deformity and guide instrumentation plans. The most popular classification systems are those proposed by King et $a^{21}$ and Lenke et al. ${ }^{20}$ In the Lenke system, in addition to the deformity in the coronal plane, the thoracic deformity in the sagittal plane (sagittal modifier) and the translation of the apical vertebra of the lumbar curve (lumbar modifier) are also considered. The Lenke system has been shown to be more precise in guiding fusion levels in the treatment of scoliosis.

AIS is more prevalent in females. ${ }^{23}$ In our case series, we found a great similarity to the current literature. We had 22 female patients (88\%) and 3 male patients (12\%) diagnosed with idiopathic scoliosis, data similar to those of Kadoury et al who reported results with $83.9 \%$ women and $16.1 \%$ men.

The average age of our patients at the time of surgery was 14.2 years, a value very close to that obtained by Kadoury et $a^{23}$, which was 15.3 years of age with a variation of \pm 2.3 years.

Modern, multi-segmental instrumentation systems involve numerous options for spinal fixation and enable different techniques for correcting deformity. ${ }^{15}$

Segmental instrumentation with pedicle screws permits better correction of deformities in the coronal, sagittal, and rotational planes, less reduction loss, shorter constructions, and it improves pulmonary function without increasing neurological complications when compared with instrumentation with hooks or hybrid instrumentation (proximal hooks and distal pedicle screws). ${ }^{10-13,24}$ This information agrees with our findings where, in the total case series of 25 cases, all of whom underwent surgery, we performed short constructions (an average of 8.4 levels involved/patient), obtained a high percentage of correction (66.4\% in the main curve), and there were no procedurerelated complications

Kim et $a /^{10,13}$ analyzed assemblies using screws, hooks, and screws in combination with hooks (hybrid). They reported that assemblies using only screws achieved better coronal reduction than hybrid or hook instrumentations. Lowenstein et $\mathrm{a}^{25}$ also observed a trend towards better correction of the main thoracic curve in cases where only screws were used.

The factors that determine the viability of posterior approach surgical correction of deformities include the magnitude of the curve, the flexibility of the curve, the extent of liberation of the posterior elements, the number of fixation points, and the correct identification of the stable vertebra. ${ }^{26}$

In our study, all the patients underwent the same surgical liberation procedure. The deformity correction technique was performed via a posterior approach, with instrumentation with pedicle screws in all the vertebrae included in the arthrodesis. We achieved a percentage of correction of $44.5 \%$ in the proximal thoracic curve, of $66.4 \%$ in the main thoracic curve, and of $59.6 \%$ in the lumbar/thoracolumbar curve. These findings were similar to the results in recent publications of an average correction of $71.9 \%$. $^{10,13,24}$

A case example is shown in Figure 1 in which the patient had the following preoperative angle measurements: main thoracic curve of $60^{\circ}$, lumbar curve of $45^{\circ}$, kyphosis of $18^{\circ}$, and lordosis of $20^{\circ}$. Following

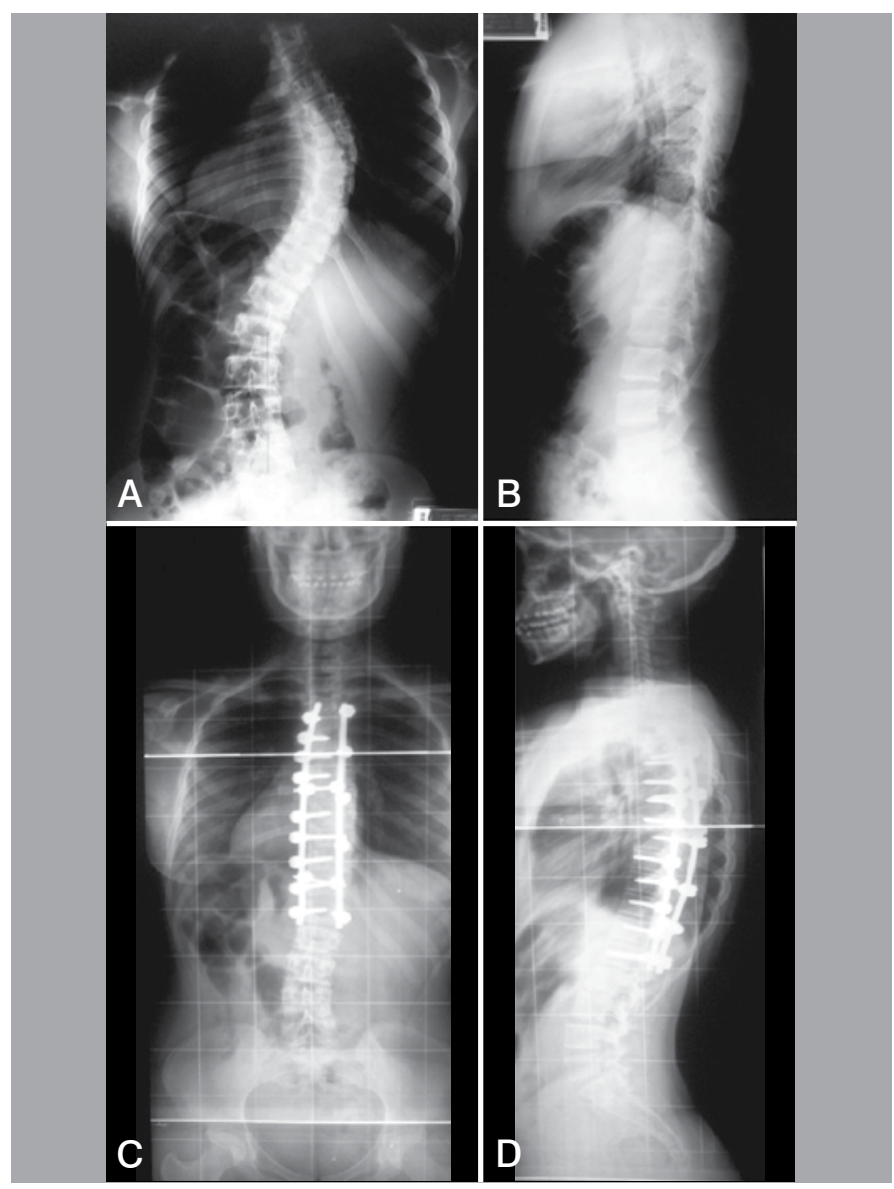

Figure 1. Clinical case. (A) Preoperative x-ray in AP. (B) Preoperative $x$-ray in $P$. (C) Postoperative $x$-ray in AP. (D) Postoperative $x$-ray in P. 
surgical treatment, the patient had a satisfactory outcome: main curve of $10^{\circ}$, lumbar curve of $8^{\circ}$, kyphosis of $25^{\circ}$, and lordosis of $52^{\circ}$.

A better understanding of sagittal spinal balance has been the focus of many recent studies. Patients with inadequate sagittal balance following surgery for scoliosis can develop flat back syndrome. ${ }^{9}$ Newton et $a^{27}$ demonstrated that there is a direct relationship between thoracic kyphosis and lumbar lordosis. Patients who presented hypokyphosis postoperatively also tended to present rectification of the lumbar lordosis, precipitating the appearance of flat back syndrome. In the analysis of our case series, we were not able to identify this relationship.

Correction of the spinal profile is increasingly reported in publications. However, most authors do not distinguish the outcomes of patients with normal thoracic kyphosis from the preoperative hypokyphotic patients. In general, posterior instrumentation tends to reduce thoracic kyphosis (TK) while anterior instrumentation tends to increase it.28

Kim et $\mathrm{a}^{10,13}$ and Lowenstein et $\mathrm{a}^{25}$ reported a significant reduction in thoracic kyphosis in patients who underwent surgery using only pedicle screws

Suk et $\mathrm{a}^{28}$, in their large series of 203 patients with 5 years of follow-up, observed an average increase in TK of 5 degrees. De Jonge et al ${ }^{18}$ observed an increase of $12^{\circ}$ in the thoracic kyphosis of hypokyphotic patients $\left(<20^{\circ}\right)$ who underwent surgical treatment using hooks. All these conflicting outcomes demonstrate the difficulty in restoration of TK. ${ }^{19}$
In our case series, we observed that the patients with AIS tended to be hypokyphotic and that by using an instrumentation technique including all the vertebrae in the arthrodesis, our final outcome was an increase in thoracic kyphosis, resulting in all patients being normokyphotic at the end of treatment.

Comparison of the average preoperative kyphosis with the average postoperative kyphosis shows an increase of $2 \%$. This value may seem small, but our sample is made up of patients with general AIS and not only preoperative hypokyphotic patients with AIS. In our sample, if we analyze only the patients with hypokyphosis $<20^{\circ}$ (10 cases), we get an average correction of the kyphosis of $10.8^{\circ}$ to $20.1^{\circ}$, documenting a gain of $9.3^{\circ}$. If we consider the cases with hypokyphosis $<10^{\circ}$ (four cases) and analyze our outcomes, we report an average kyphosis evolving from $5.5^{\circ}$ preoperatively to $20.2^{\circ}$ postoperatively, representing a correction of $14.7^{\circ}$.

\section{CONCLUSION}

Radiographic evaluation of the sagittal curves of patients with AIS surgically treated with pedicle screws in all the vertebrae included in the arthrodesis showed satisfactory outcomes in relation to the maintenance of thoracic kyphosis.

All authors declare no potential conflict of interest concerning this article.

\section{REFERENCES}

1. Kesling KL, Reinker KA. Scoliosis in twins. A meta-analysis of the literature and report of six cases. Spine (Phila Pa 1976). 1997;22(17):2009-14.

2. Parent S, Newton PO, Wenger DR. Adolescent idiopathic scoliosis: etiology, anatomy natural history, and bracing. Instr Course Lect. 2005;54:529-36.

3. Weiss HR. Adolescent idiopathic scoliosis (AIS) - an indication for surgery? A systematic review of the literature. Disabil Rehabil. 2008:30(10):799-807.

4. Weiss HR, Goodall D. The treatment of adolescent idiopathic scoliosis (AIS) according to present evidence: a systematic review. Eur J Phys Rehabil Med. 2008;44(2):177-93.

5. Haher TR, Merola A, Zipnick RI, Gorup J, Mannor D, Orchowski J. Meta-analysis of surgical outcome in adolescent idiopathic scoliosis: a 35-year English literature review of 11,000 patients. Spine (Phila Pa 1976). 1995;20(14):1575-84.

6. Winter RB, Lonstein JE, Denis F. How much correction is enough? Spine (Phila Pa 1976) 2007:32(24):2641-3.

7. Lenke LG, Kuklo TR, Ondra S, Polly DW Jr. Rationale behind the current state-of-the-art treatment of scoliosis (in the pedicle screw era). Spine (Phila Pa 1976). 2008;33(10):1051-4

8. Westrick ER, Ward WT. Adolescent idiopathic scoliosis: 5-year to 20-year evidence-based surgical results. J Pediatr Orthop. 2011;31(Suppl 1):S61-8.

9. Thompson JP, Transfeldt EE, Bradford DS, Ogilvie JW, Boachie- Adjei O. Decompensation after Cotrel-Dubousset instrumentation of idiopathic scoliosis. Spine (Phila Pa 1976). 1990:15(9):927-31.

10. Kim YJ, Lenke LG, Cho SK, Bridwell KH, Sides B, Blanke K. Comparative analysis of pedicle screw versus hook instrumentation in posterior spinal fusion of adolescent idiopathic scoliosis. Spine (Phila Pa 1976). 2004;29(18):2040-8.

11. Hamill CL, Lenke LG, Bridwell KH, Chapman MP, Blanke K, Baldus C. The use of pedicle screw fixation to improve correction in the lumbar spine of patients with idiopathic scoliosis. Is it warranted? Spine (Phila Pa 1976). 1996:21(10):1241-9.

12. Suk SI, Kim WJ, Lee SM, Kim JH, Chung ER. Thoracic pedicle screw fixation in spinal deformities: are they really safe? Spine (Phila Pa 1976). 2001;26(18):2049-57.

13. Kim YJ, Lenke LG, Kim J Bridwell KH, Cho SK, Cheh G, Sides B. Comparative analysis of pedicle screw versus hybrid instrumentation in posterior spinal fusion of adolescent idiopathic scoliosis. Spine (Phila Pa 1976). 2006;31(3):291-8.

14. La Grone MO. Loss of lumbar lordosis. A complication of spinal fusion for scoliosis. Orthop Clin North Am. 1988:19(2):383-93.

15. Bridwell KH. Surgical treatment of idiopathic adolescent scoliosis. Spine (Phila Pa 1976). 1999:24(24):2607-16
16. Tis JE, O'Brien MF, Newton PO, Lenke LG, Clements DH, Harms J, Betz RR. Adolescent idiopathic scoliosis treated with open instrumented anterior spinal fusion: five-year followup. Spine (Phila Pa 1976):35(1):64-70.

17. Roussouly P, Gollogly S, Berthonnaud E, Dimnet J. Classification of the normal variation in the sagittal alignment of the human lumbar spine and pelvis in the standing position. Spine (Phila Pa 1976). 2005:30(3):346-53

18. de Jonge T, Dubousset JF, Illés T. Sagittal plane correction in idiopathic scoliosis. Spine (Phila Pa 1976). 2002;27(7):754-60.

19. Cobb JR. Outline for the study of scoliosis. Instr Course Lect. 1948;5:261-75.

20. Lenke LG, Betz RR, Harms J, Bridwell KH, Clements DH, Lowe TG, et al. Adolescent idiopathic scoliosis: a new classification to determine extent of spinal arthrodesis. J Bone Joint Surg Am. 2001;83(8):1169-81.

21. King HA, Moe JH, Bradford DS, Winter RB. The selection of fusion levels in thoracic idiopathic scoliosis. Bone Joint Surg Am. 1983;65(9):1302-13.

22. Moe JH. Methods of correction and surgical techniques in scoliosis. Orthop Clin North Am. 1972:3(1):17-48

23. Kadoury S, Cheriet $F$, Beauséjour $M$, Stokes IA, Parent $S$, Labelle H. A three-dimensional retrospective analysis of the evolution of spinal instrumentation for the correction of adolescent idiopathic scoliosis. Eur Spine J. 2009:18(1):23-37.

24. Suk SI, Lee CK, Kim WJ, Chung YJ, Park YB. Segmental pedicle screw fixation in the treatment of thoracic idiopathic scoliosis. Spine (Phila Pa 1976). 1995;20(12):1399-405

25. Lowenstein JE, Matsumoto H, Vitale MG, Weidenbaum M, Gomez JA, Lee FY, et al Coronal and sagittal plane correction in adolescent idiopathic scoliosis: a comparison between all pedicle screw versus hybrid thoracic hook lumbar screw constructs. Spine (Phila Pa 1976). 2007:32(4):448-52.

26. Muschik M, Schlenzka D, Robinson PN, Kupferschmidt C. Dorsal instrumentation for idiopathic adolescent thoracic scoliosis: rod rotation versus translation. Eur Spine J. 1999:8(2):93-9.

27. Newton PO, Yaszay B, Upasani WV, Pawelek JB, Bastrom TP, Lenke LG, et al. Preservation of thoracic kyphosis is critical to maintain lumbar lordosis in the surgical treatment of adolescent idiopathic scoliosis. Spine (Phila Pa 1976). 2010;35(14):1365-70.

28. Suk SI, Lee SM, Chung ER, Kim JH, Kim SS. Selective thoracic fusion with segmental pedicle screw fixation in the treatment of thoracic idiopathic scoliosis: more than 5-year follow-up. Spine (Phila Pa 1976). 2005:30(14):1602-9. 